History and the Testimony of Language 


\section{THE CALIFORNIA WORLD HISTORY LIBRARY}

Edited by Edmund Burke III, Kenneth Pomeranz, and Patricia Seed

1. The Unending Frontier: Environmental History of the Early Modern World, by John F. Richards

2. Maps of Time: An Introduction to Big History, by David Christian

3. The Graves of Tarim: Genealogy and Mobility across the Indian Ocean, by Engseng Ho

4. Imperial Connections: India in the Indian Ocean Arena, 1860-1920, by Thomas R. Metcalf

5. Many Middle Passages: Forced Migration and the Making of the Modern World, edited by Emma Christopher, Cassandra Pybus, and Marcus Rediker

6. Domesticating the World: African Consumerism and the Genealogies of Globalization, by Jeremy Prestholdt

7. Servants of the Dynasty: Palace Women in World History, edited by Anne Walthall

8. Island World: A History of Hawai' $i$ and the United States, by Gary Y. Okihiro

9. The Environment and World History, edited by Edmund Burke III and Kenneth Pomeranz

10. Pineapple Culture: A History of the Tropical and Temperate Zones, by Gary Y. Okihiro

11. The Pilgrim Art: Cultures of Porcelain in World History, by Robert Finlay

12. The Quest for the Lost Nation: Writing History in Germany and Japan in the American Century, by Sebastian Conrad; translated by Alan Nothnagle

13. The Eastern Mediterranean and the Making of Global Radicalism, 1860-1914, by Ilham Khuri-Makdisi

14. The Other West: Latin America from Invasion to Globalization, by Marcello Carmagnani

15. Mediterraneans: North Africa and Europe in an Age of Migration, c. 1800-1900, by Julia A. Clancy-Smith

16. History and the Testimony of Language, by Christopher Ehret 


\section{History and the Testimony of Language}

Christopher Ehret

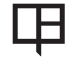

UNIVERSITY OF CALIFORNIA PRESS

Berkeley Los Angeles London 
University of California Press, one of the most distinguished university presses in the United States, enriches lives around the world by advancing scholarship in the humanities, social sciences, and natural sciences. Its activities are supported by the UC Press Foundation and by philanthropic contributions from individuals and institutions. For more information, visit www.ucpress.edu.

University of California Press

Berkeley and Los Angeles, California

University of California Press, Ltd.

London, England

(c) 2011 by Christopher Ehret

Library of Congress Cataloging-in-Publication Data

Ehret, Christopher.

History and the testimony of language / Christopher Ehret.

p. $\mathrm{cm}$.

Includes bibliographical references and index.

ISBN 978-0-520-26204-1 (cloth : alk. paper) -

ISBN 978-0-520-26205-8 (pbk. : alk. paper)

1. History-Methodology. 2. Language and history. 3. Social history. 4. Africa-History. I. Title.

D16.135.E57 2011

$907.2-\mathrm{dc} 22$

2010001040

Manufactured in the United States of America
$\begin{array}{llllllllll}20 & 19 & 18 & 17 & 16 & 15 & 14 & 13 & 12 & 11\end{array}$
$\begin{array}{llllllllll}10 & 9 & 8 & 7 & 6 & 5 & 4 & 3 & 2 & 1\end{array}$

This book is printed on Cascades Enviro 100, a 100\% post consumer waste, recycled, de-inked fiber. FSC recycled certified and processed chlorine free. It is acid free, Ecologo certified, and manufactured by BioGas energy. 
In memoriam Patricia Durousseau, Laura Fliegelman, Madoda Hlatshwayo, John Ochieng, and Gloria Waite, young scholars of history, taken from us before their time 
This page intentionally left blank 